\title{
O lado oculto das prisões femininas: \\ representações dos sentimentos em torno do crime e da pena.
}

Elaine Pimentel ${ }^{1}$

Resumo: O artigo faz uma reflexão crítica sobre o encarceramento feminino, através de um diálogo profícuo entre a criminologia e a teoria feminista, destacando a necessidade de o Estado desenvolver um olhar diferenciado, promovendo políticas públicas, para as mulheres que sofrem os efeitos do cárcere $\mathrm{e}$ do pós-cárcere. O texto dá voz a três mulheres que expressam suas dores e sofrimentos vivenciados a partir do cárcere onde sofreram o processo de mortificação do eu, nos moldes conceituais de Erving Goffman.

Palavras-chave: Prisão feminina, política pública, sofrimento.

Abstract: This article is a critical reflection on female incarceration, through a fruitful dialogue between criminology and feminist theory. It highlights the need for the state to develop a different approach by promoting public policies for women who suffer the effects of incarceration and post -prison. The text gives voice to three women who express their pain and suffering experienced from the jail where they underwent the process of mortification of the self, the conceptual lines of Erving Goffman.

Key words: women's prison, public policy, suffering.

\section{Apresentação}

A realidade do sistema prisional brasileiro tem sido alvo de importantes reflexões acadêmicas, transformando-se num objeto de estudo imprescindível à própria compreensão da dinâmica da violência e da criminalidade na sociabilidade contemporânea. É relativamente consensual a percepção de que a precariedade e a insuficiência da organização prisional incidem como fatores condicionantes para as dificuldades na reintegração social dos sujeitos que cometeram crimes e, notadamente, das mulheres.

O presente trabalho propõe uma discussão sócio-histórica acerca das peculiaridades da criminalidade e do encarceramento feminino no Brasil, com o objetivo de analisar os efeitos subjetivos da prisão sobre mulheres que cometeram crimes. A forma como a sociedade se relaciona com essas mulheres é decisiva para

${ }^{1}$ E-mail: elainepimentelcosta@yahoo.com.br. Doutora em Sociologia, UFPE.

Latitude, Vol. 7, no 2, pp. 51-68, 2013 
O lado oculto das prisões femininas: representações dos sentimentos em torno do crime e da pena.

as representações que produzem em torno de si mesmas. Por meio da narrativa de três histórias de mulheres que vivenciaram a experiência do cárcere, evidenciaremos situações de dor e sofrimento em função de reações discriminatórias e preconceituosas, tanto por parte da sociedade, como por parte dos familiares. Seus relatos dão visibilidade aos sentimentos que vivenciam, particularmente quando percebem a não aceitação da condição de ex-presidiárias, principalmente pelas pessoas que compõem seu universo afetivo: pais, mães, filhos/as, companheiro/as.

Ainda que as mutações culturais tenham produzido deslocamentos significativos em relação ao lugar da mulher no contexto social, continua presente no imaginário coletivo a percepção de que as mulheres cumprem um papel maternal marcado, principalmente, pela capacidade amorosa e acolhedora que conseguem estabelecer, seja no espaço privado ou no espaço público. Assim, o envolvimento de mulheres na criminalidade repercute de forma muito peculiar nesse imaginário coletivo, sobretudo porque as expectativas sobre o comportamento feminino são rompidas com a prática de um delito. Ou seja, os gestos amorosos, cuidadosos e atenciosos atribuídos tradicionalmente à figura da mulher, são vistos como incompatíveis às práticas delituosas.

$\mathrm{O}$ discurso das mulheres que vivenciaram a experiência do cárcere permite-nos evidenciar algo que escapa ao senso comum: o ato criminoso não representa, necessariamente, a negação de outros elementos identitários que as constituem como sujeitos femininos, já que as mulheres que vivem a experiência do crime e do cárcere continuam sendo mães, esposas, filhas, amigas, profissionais etc.

O aumento significativo do número de mulheres que cumprem pena privativa de liberdade, no Brasil, sinaliza a crescente presença de mulheres em ações criminosas. Ao mesmo tempo, o olhar sobre a realidade dos cárceres femininos confirma o quanto o sistema penitenciário está despreparado para lidar com as especificidades de gênero. Políticas criminais alheias a questões femininas desembocam em um tratamento uniforme para mulheres e homens, o que tende a prejudicar severamente a função reintegradora da pena privativa de liberdade, de modo que a pena passa a ser mero sinônimo de castigo. A realidade aponta que, a despeito de sua ineficiência, a custódia penal satisfaz os anseios da sociedade brasileira, especialmente diante do alarmante crescimento da criminalidade. Nessa conjuntura, as questões de ordem subjetiva, vivenciadas pelas mulheres encarceradas, permanecem no campo da invisibilidade. Se, de fato, os silêncios sobre a história das mulheres também se expressam no pensamento criminológico, mais forte ainda é o desconhecimento ou mesmo o desinteresse social em relação do que se passa com as mulheres que vivem atrás das grades. 
Ao darmos voz às mulheres presas², identificamos que algumas situações concretas da transgressão feminina representam, efetivamente, uma negação das expectativas pessoais e sociais construídas em torno das representações atribuídas à condição de ser mulher. Não estão em foco, aqui, os delitos cometidos por mulheres, mas sim os efeitos que esses atos produzem em suas vidas, já que, com o cumprimento da pena, ficam submetidas a uma realidade de distanciamento e segregação social, particularmente em relação à família, aos amigos, à profissão, rompendo, além disso, com todas as expectativas culturais construídas em torno da condição de ser mulher em nossa sociedade.

\section{Problematizando crimes e encarceramento feminino no Brasil}

A prática de crimes por mulheres não é um fenômeno recente, mas, no Brasil, as estatísticas revelam um aumento significativo do número de mulheres envolvidas em diversas expressões da criminalidade. Dados do Conselho Nacional de Política Criminal e Penitenciária, ligado ao Ministério da Justiça ${ }^{3}$, demonstram o crescimento acentuado da população carcerária feminina na última década, proporcionalmente maior do que o aumento que aconteceu no universo masculino. Enquanto, em 2001, o número de mulheres em cumprimento de pena nos regimes fechado e semiaberto, e submetidas à medida de segurança na modalidade internação era de 5.517, em 2005 esse número sobe para 8.484 e, em 2010, para 16.612. Isso significa um aumento de $301,1 \%$ em uma década. Já a população carcerária masculina, embora maior em números reais - 159.210 homens, em 2001 e 244.784, em 2010 -, apresentou um aumento de 153,7\%, ou seja, metade do crescimento da população carcerária feminina.

Esses dados sinalizam o expressivo aumento do número de mulheres envolvidas em práticas criminosas, algo que, por si só, enseja interesse sociológico. Por que é crescente o envolvimento de mulheres em crimes? Que elementos podem contribuir para a compreensão desse fenômeno? Em importante resgate de teorias criminológicas que buscam compreender a delinquência feminina, Duarte (2011, p. 176) aponta três linhas de investigação sociológica que se destacaram nos estudos mais antigos sobre o tema: a) a promiscuidade sexual; b) a patologização do comportamento da mulher; c) a masculinização do comportamento feminino.

${ }^{2}$ Os relatos apresentados neste texto foram coletados para a tese de doutorado de Elaine Cristina Pimentel Costa, intitulada "Enfim a liberdade: as mulheres e a vivência póscárcere", defendida em 2011, no Programa de Pós-Graduação em Sociologia da Universidade Federal de Pernambuco (UFPE), Brasil.

${ }^{3}$ http://portal.mj.gov.br/cnpcp/data/Pages/MJD574E9CEITEMIDC37B2AE94C6840068B1624 D28407509CPTBRIE.htm

Latitude, Vol. 7, no 2, pp. 51-68, 2013

DOI: https://doi.org/10.28998/2179-5428.20130204 
O lado oculto das prisões femininas: representações dos sentimentos em torno do crime e da pena.

Pondera, então, que somente as perspectivas feministas proporcionaram um olhar mais crítico sobre a questão. No mesmo sentido, Gelsthorpe (2002) defende que essa aproximação entre a criminologia o feminismo não foi resultado de um movimento do pensamento criminológico, mas sim dos esforços das intelectuais feministas, que procuraram desenvolver uma criminologia atenta às questões de sexo e gênero. Somente com essa articulação teórica, novos elementos, de natureza sociológica, passam a compor o cenário de reflexões sobre os desvios femininos.

Embora não se possa falar em uma criminalidade tipicamente feminina, já que o crime comentido por mulheres está inserido no contexto da criminalidade em geral, é preciso reconhecer, a partir de pesquisas sobre o tema, que há uma certa divisão sexual do trabalho nos crimes, expressa, sobretudo, na maior participação de mulheres em ações criminosas estratégicas, a exemplo do tráfico de drogas - como "mulas" ${ }^{4}$, no tráfico difuso, interno ou internacional -, crime que mais leva mulheres à prisão (COSTA, 2009). Isso, porém, não diminui a participação de mulheres em crimes violentos, como o homicídio, segundo lugar nas estatísticas criminais femininas (ALMEIDA, 2001), delitos contra o patrimônio, contra a dignidade sexual ou outros, praticados individualmente ou em coautoria. Na realidade, a pluralidade de formas de participação de mulheres em crimes sugere a impossibilidade de se compor uma etiologia criminal que explique plenamente as motivações para o envolvimento feminino (ver KLEIN, 1982). Cada caso traz consigo as peculiaridades das histórias de vida, das experiências e, portanto, das razões que impulsionaram as práticas criminosas, que podem ser habituais - pois implicam na própria subsistência da mulher e de sua família -, ou eventuais, motivadas por situações específicas das mais diversas ordens.

Não são poucas as teorias feministas que procuram explicar o fenômeno do crime cometido por mulheres. Blanchette e Brouwn (2007) identificam as seguintes linhas teóricas para a explicação da delinquência feminina: teorias neutras às questões de gênero (teorias do controle, teorias do aprendizado social, teorias do reforço pessoal, social e comunitário, perspectivas do curso da vida, psicologia evolutiva e teorias biológicas); teorias centradas no feminino (teorias da liberação ou emancipação feminina, teorias da marginalização econômica, teorias integradas da liberação e da marginalização econômica, teorias da socialização, teorias relacionais, terias do controle do poder e teorias feministas); teorias híbridas (teorias do esforço e teorias de gênero). No entanto, é preciso reconhecer que esses caminhos teóricos jamais conseguiriam se aproximar de uma teoria geral da criminalidade feminina, que explicasse a pluralidade de condutas, motivações e justificativas para a delinquência feminina. 4 "Mulas" são as mulheres que carregam as drogas consigo - na bagagem, nas vestes ou no
estômago, por ingestão -, sobretudo em voos internacionais entre América Latina e Europa. 
No mesmo sentido são os estudos sobre a prisão: perspectivas teóricas e sócio-históricas que se tornaram importantes referências para o estudo da prisão, dedicaram-se a pensar o cárcere a partir do ponto de vista masculino, ignorando por completo a existência das mulheres (ver BECCARIA, 2003; FOUCAULT, 1997; GOFFMAN, 2003). Assim como o pensamento criminológico, os estudos sobre pena e cárcere numa perspectiva de gênero devem muito às diversas expressões do feminismo, que cuidaram dessa aproximação. Carlen (2003), Worral (2003), Wilkinson (2006) e Cunha (2007) são alguns exemplos dessas contribuições teóricas.

No Brasil, alguns estudos também dão visibilidade ao debate do encarceramento feminino, lançando luzes sobre questões do cotidiano prisional feminino, em perspectivas metodológicas que transitam entre o objetivo estatístico, contextualizante -, e o subjetivo, centrado nos discursos das mulheres presas. Destacam-se, nesse sentido, os estudos de Perruci (1983), Lemgruber (1999), Mello (2000), Alves (2001), Soares (2002), Espinosa (2004), Mattos (2008). São estudos quantitativos e qualitativos que trazem importantes contribuições para a compreensão da sociabilidade nas prisões femininas em diversos estados brasileiros, como Rio de Janeiro, Pernambuco, Sergipe, Minas Gerais, e que, já na década de 1980, indicavam questões importantes para a compreensão do cotidiano carcerário das mulheres.

Se no campo teórico os avanços historiográficos são tímidos, mais frágeis ainda são as políticas públicas especificamente dirigidas para as mulheres encarceradas. Não é equivocado afirmar que, no Brasil, o sistema penal é despreparado para lidar com mulheres que cumprem pena pelo cometimento de crimes. Os silêncios da história com relação às mulheres - tão bem debatidos por Perrot $(2005,2007,2010)$-, possuem contornos bastante peculiares no campo das políticas prisionais.

Segundo Cunha (2007), a designação "prisões masculinas" não é comumente utilizada quando os ocupantes desses estabelecimentos penais são homens. "A maioria das vezes a expressão só emerge por contraposição à de 'prisões femininas', essa sim inescapável quando são mulheres os reclusos em questão" (CUNHA, 2007, p. 1). Isso significa que o termo prisão, por si só, traz implícito o adjetivo masculino. Quando se menciona prisão, é o universo masculino que está sendo referido. Prisões femininas são tomadas como excepcionais, já que os crimes cometidos por mulheres, em todo o mundo, representam, invariavelmente, uma parcela muito pequena dos crimes em geral. Como consequência, as necessidades específicas das mulheres tendem a permanecer em segundo plano nas políticas penitenciárias, que deveriam envolver não apenas o período de encarceramento, mas também a difícil etapa da reintegração social. 
O lado oculto das prisões femininas: representações dos sentimentos em torno do crime e da pena.

$\mathrm{O}$ argumento da igualdade legal entre mulheres e homens tende a ser utilizado como justificativa para políticas públicas assexuadas, indiferentes às vicissitudes do feminino no cárcere. Embora a igualdade na lei seja, de fato, uma conquista feminista na história recente do Brasil, ela não pode ser instrumento de negação das diferenças existentes entre mulheres e homens na vida social. No debate sobre igualdade e diferença entre mulheres e homens, Bock (2008) problematiza a forma como os conceitos de igualdade sexual ou igualdade de gênero foram utilizados como instrumento de análise, negligenciado diferenças de outra natureza - a exemplo da psicológica -, por serem comumente utilizadas como justificativa para o tratamento discriminatório das mulheres. Na busca por igual tratamento para mulheres e homens, acabaram sendo formuladas leis "em termos de neutralidade relativamente a gênero, o que, desta forma, elimina a diferença sexual transformando a masculinidade e a feminilidade em questões politicamente irrelevantes" (BOCK, 2008: p. 88). De fato, conceder tratamento absolutamente igual a mulheres e homens no campo das políticas criminais e penitenciárias é um equívoco comum, que contraria a finalidade reintegradora da pena privativa de liberdade. Outras reflexões, de matrizes políticas, também caminham no sentido de problematizar a ideia de igualdade plena, alheia às questões de gênero (ver FRASER, 2002).

O sistema de justiça penal brasileiro, de fato, não está preparado para lidar com as questões femininas, que precisam ser contempladas em políticas prisionais e de reintegração social. Em um país que proíbe constitucionalmente a pena de morte e a prisão perpétua, e em que a pena mais severa é a reclusão, a ser executada no tempo máximo de 30 anos (art. 75 do Código Penal brasileiro), somos levadas a pensar em como transformar esse espaço de reclusão num ambiente mais humano, condição imprescindível para que possa produzir algum efeito positivo na vida das encarceradas. Da mesma forma, é preciso pensar no retorno da apenada ao convívio social, sendo este aspecto da pena um imperativo da justiça penal. Observamos, no entanto, que o Estado e a sociedade civil agem como se o encarceramento fosse o marco final do sistema penal, fechando os olhos ou mesmo negligenciando um aspecto fundamental do processo de reintegração social das mulheres, que é a relação existente entre cárcere e pós-cárcere. Não se pode olvidar que a vivência dentro da prisão - inclusive experiências de abandono afetivo, estigmatização e diversas expressões da violência - tem repercussão direta na forma como mulheres condenadas vivenciarão o pós-cárcere. Para Goffman, tratase de uma constante tensão entre os mundos interno e externo, utilizada, inclusive, como mecanismo de controle no espaço penitenciário (GOFFMAN, 2003b: p. 24). Ocorre que essa separação entre "mundos" é apenas uma forma de expressar o distanciamento físico entre o espaço penitenciário e o espaço de convívio pleno, que pertencem a uma mesma sociedade, de modo que as experiências vividas 
internamente podem ser determinantes para os caminhos a serem trilhados após o retorno à liberdade.

No Brasil, as poucas políticas prisionais femininas existentes limitam-se à proteção à maternidade e ao cuidado com filhos pequenos. Embora inspiradas em normas internacionais, a exemplo das "Regras Mínimas para Tratamento de Reclusos" (Genebra, 1955), "Reglas de las Naciones Unidas para el tratamiento de las reclusas y medidas no privativas de la libertad para las mujeres delincuentes" (Regras de Bangkok, 2010) e em lei internas, como a Constituição Federal e a Lei de Execuções Penais (Lei $n^{\circ} 7.210 / 84$ ), todas de matrizes humanitárias, as poucas políticas de tratamento no cárcere e de reintegração social não são suficientes para garantir a permanência ou o resgate dos vínculos afetivos durante o encarceramento, nem tampouco para preparar as mulheres, profissionalmente, para o mercado de trabalho. Somam-se a isso as muitas situações de violação dos direitos das reclusas, diante da precariedade da estrutura física do espaço penitenciário, do despreparo do staff penitenciário para lidar com mulheres presas e da fragilidade de políticas penitenciárias - atentas às questões afetivas e profissionais das mulheres - durante o cumprimento da pena e o pós-cárcere.

Por tudo isso, o cotidiano carcerário amplia consideravelmente as vivências negativas em torno da segregação imposta pela prisão, implicando em forte sofrimento para as mulheres, tanto com relação ao cumprimento da pena em si, como na expectativa do futuro. É o que Foucault chama de "sofrimento da alma" (FOUCAULT, 1987, p. 14).

De um panorama macrossociológico sobre a questão carcerária feminina que revela as fragilidades estruturais do sistema de justiça penal - para um olhar microssociológico (Goffman, 1985) sobre as mulheres que vivenciam a experiência do cárcere, muito escapa a uma percepção superficial. Há, de fato, um lado oculto, somente visualizado quando é dada voz a essas mulheres, para que expressem as representações que rodeiam temas como crime, prisão, família, profissão, futuro.

\section{Sobre o sofrimento feminino no cárcere}

Assinalamos a particularidade do sofrimento das mulheres encarceradas, tomando como parâmetro a perplexidade que seu ato criminoso produz no universo social e familiar em que está inserida. A primeira repercussão produzida pelo ato criminoso é a sua desconfiguração identitária como mulher, fator que produz implicações profundas em sua autoimagem de sujeito feminino, na esteira do que argumentamos anteriormente sobre as tradicionais atribuições do ser feminino na sociedade ocidental. Há uma singularidade na relação de cada mulher com o crime praticado, bem como existem dessemelhanças no trato da questão em termos da repercussão do crime sobre sua vida; mas, algo identifica todas essas mulheres: suas experiências pessoais na esfera criminal passam a compor seu 
O lado oculto das prisões femininas: representações dos sentimentos em torno do crime e da pena.

universo representacional, implicando que nenhuma delas fica a salvo do sofrimento em relação ao acontecimento que lhes determinou a condição de presidiárias. A forma como vivenciará o encarceramento estará intimamente ligada com sua vivência antes da prisão, mas é comum, entre as mulheres, o sentimento de punição em duplicidade, pois o cometimento de crimes significa tanto o descumprimento das normas jurídicas penais, como também as chamadas "normas de gênero" (HEIDENSOHN, 2002, p. 504), que atribuem às mulheres status e papéis aparentemente incompatíveis com o crime.

As narrativas das mulheres que cometeram crimes e que vivenciaram a experiência do cárcere demonstram que o sofrimento é um sentimento que passa a acompanhá-las em seu cotidiano, tanto na esfera do cárcere como no momento em que passam a viver o processo de reintegração social no pós-cárcere. Para além dos sentimentos de remorso, arrependimento e vergonha vivenciados como resultado do crime cometido, o cárcere, verdadeiro espaço de segregação social, tem implicações peculiares na sociabilidade das apenadas, repercutindo tanto na esfera afetiva como nas relações sociais mais impessoais, a exemplo do campo profissional. Portanto, ainda que o sofrimento não esteja localizado na relação da autora com o crime em si, é possível que se expresse no cotidiano do cárcere ou mesmo no pós-cárcere, momento de retorno ao convívio social pleno.

Se tanto os homens como as mulheres podem vivenciar esse tipo de sofrimento, por que, então, abordar as peculiaridades do sofrimento feminino na prisão? Teriam as mulheres alguma característica particular que as diferencia, nesse aspecto, dos homens? O que poderia ser identificado como específico ao universo feminino que colocaria as mulheres numa situação distinta, em se tratando de sofrimento no cárcere e no pós-cárcere?

Algumas reflexões podem lançar luzes sobre essas questões. A abordagem do sofrimento produzido nas mulheres no cárcere e no pós-cárcere significa, de certa forma, um rompimento com a compreensão, ainda hegemônica em nossa sociedade, de que aquelas que cometem crimes não são humanas, não merecem ser tratados como tais, nem deveriam ser reconhecidos como portadores de direitos humanos. Muitos não reconhecem as experiências de mortificação do sujeito (GOFFMAN, 2003) e as perdas afetivas e subjetivas vivenciadas nos cárceres femininos como um sofrimento, mas sim como merecimento. Dessa forma, a população carcerária feminina acaba sendo alvo de múltiplos preconceitos e discriminações, de modo que a aceitação da violação dos diretos em relação às detentas expressa uma postura de "exclusão moral" que se sustenta na ideia de que algumas pessoas não têm "direito a ter direitos". As palavras de Cardia (1995) expressam bem essa realidade:

$\mathrm{O}$ ato criminal retiraria do criminoso seus direitos e o colocaria fora da comunidade moral: os presos representam uma ameaça tão profunda que faz com que sejam excluídos 
do mundo dos humanos. No limite da exclusão nega-se aos excluídos o direito à vida (Cardia, 1995, p. 371).

O mecanismo subjetivo que permite a prática de exclusão moral é a "desativação dos mecanismos de autocontrole moral" (Cardia, 1995, p. 371), por meio dos quais algumas ações bárbaras passam a ser aceitas, desde que sejam dirigidas contra pessoas consideradas inferiores, inadequadas, anormais, doentes, diferentes ou desiguais. Nesse sentido, pessoas que cometeram crimes - mulheres, no caso do presente estudo -, portanto, podem ser maltratadas, humilhadas, torturadas ou mortas, sem que essas práticas sejam percebidas como violação de direitos.

Na verdade, ainda é forte a visão de que a pena deve ser marcada pelo castigo, numa perspectiva de vingança e retaliação. Cultiva-se uma associação entre punição, dor e sofrimento, na medida em que se considera que o sujeito só "paga" pelo crime cometido se vivenciar situações de suplício e expiação. Os que partilham desse pensamento, o fazem porque reduzem o sujeito que cometeu um crime ao ato praticado. Dessa forma, uma mulher que assassinou alguém passa a ser identificada apenas como assassina, uma outra que roubou algo de alguém é rotulada de ladra e uma mulher que se envolveu com a atividade ilícita do tráfico de drogas será categorizada apenas como traficante. As outras dimensões da existência dessas mulheres - filhas, esposas, mães, amigas etc. - e os respectivos papeis sociais assumidos durante sua vida, tendem a ser desconsiderados. Nesses termos, no espaço do cárcere, todas são reduzidas a uma categoria: a de criminosas. Os exemplos poderiam se estender por todos os crimes dispostos na legislação penal, mas pode-se afirmar que esses rótulos, por si só, já produzem a mortificação das mulheres, nos termos postos por Goffman (2004), ao abordar os efeitos das instituições totais sob a subjetividade humana.

De fato, a representação social da mulher, bem como sua autorrepresentação, tendem a ficar comprometidas pelo cometimento de um ato criminoso, porque a transgressão representa uma ruptura em relação às expectativas sociais constituídas em torno da concepção do que é ser mulher. É certo que há sociedades em que as mulheres assumem o comando autoritário de suas tribos ou comunidades, distanciando-se, assim, da imagem de mulher meiga e delicada, como a que foi construída, particularmente, nas sociedades ocidentais. Alimena (2010) identifica uma comunidade tribal existente no Congo (tribo conhecida como Lele), onde as mulheres dominavam os homens por meio de estratégias e artimanhas no campo da sedução, criando situações em que os homens ficavam absolutamente vulneráveis e enfraquecidos diante dos estratagemas de conflitos criados pelas mulheres, inviabilizando, assim, a dominação masculina no espaço social (ver Alimena, 2010, p. 10).

Latitude, Vol. 7, no 2, pp. 51-68, 2013 
O lado oculto das prisões femininas: representações dos sentimentos em torno do crime e da pena.

A visão essencialista, estática e reducionista do que é ser mulher sempre esteve na mira de profundas críticas por parte dos movimentos feministas. Porém, as representações sociais hegemônicas em todo o mundo tendem a atribuir às mulheres elementos identitários aparentemente incompatíveis com a condição de criminosa. Assim, a identidade de uma mulher que cometeu um crime fica categoricamente comprometida e essa mulher passa a ser condenada não somente pelo crime que cometeu, mas, principalmente, porque não correspondeu aos atributos femininos culturalmente instituídos e que as identificam naturalmente como pessoas bondosas, amorosas, românticas, gentis, compreensivas, maternais, meigas e angelicais.

Uma vez presas, as mulheres que cometeram delitos passam pela experiência de refletir sobre o crime cometido, a separação da família e a profissão perdida. O tempo vivido na prisão introduz em seu universo representacional reflexivo temas que passam a compor sua vida a partir da experiência do cárcere, do distanciamento em relação à família e da perda dos referenciais profissionais. Além disso, o encarceramento, por si só, proporciona a essas mulheres outro olhar sobre o futuro, normalmente permeado por sentimentos de arrependimento, vergonha e medo diante do porvir, sobretudo porque, já na prisão, passam a sofrer os impactos subjetivos produzidos pelo estigma de ser presidiária, além do sofrimento que experimentam no pós-cárcere, já que não esquecem as marcas do crime e do tempo vivido na prisão.

\section{Representações sociais sobre mulheres, crime, cárcere e sofrimento}

Nas três narrativas adiante apresentadas, fatos e circunstâncias das vidas de mulheres que passaram pela experiência do cárcere demonstram bem como o crime cometido e a vivência na prisão colocam essas mulheres em situações geradoras de muitas dores e sofrimentos, provocando reflexões sobre a radicalidade do ato cometido.

\subsection{Rosa}

Rosa tem 28 anos e é uma mulher muito bonita. Alta, possui longos cabelos loiros cacheados e olhos verdes. É vaidosa e gosta de usar roupas curtas e coloridas. Sua aparência e a forma como se comporta - através de gestos sensuais revelam a performance de sua feminilidade de acordo com padrões tradicionais.

Filha única de uma família de classe média baixa, Rosa cursou até a $8^{a}$ série (não concluída) e não levou os estudos adiante, segundo ela, porque se envolveu com drogas. Nunca havia trabalhado antes de ser presa e era sustentada pelo pai, que faleceu há cerca de um ano. Chora ao falar do pai porque lembra o quanto ele ficou magoado com o crime cometido por ela, a ponto de não visitá-la na prisão 
durante os quatro anos em que permaneceu encarcerada. Como filha única, encontrava no pai, na mãe e na filha mais velha, já nascida quando ela foi presa, os seus principais laços afetivos, pois eram as pessoas mais importantes de sua vida. Essas ligações afetivas aparecem em seu relato como referênciasidentitárias fortes.

Rosa experimenta várias situações em que afirma ter sofrido os efeitos do cárcere, particularmente, ao ser vítima de preconceito e da discriminação. $\mathrm{Na}$ verdade, sua identidade passa a ser prioritariamente a identidade de alguém que foi condenada por um crime e, mesmo tendo cumprido sua pena, carregará para sempre o estigma de ex-presidiária. Dentre outros relatos, Rosa partilha a grande dificuldade que enfrentou para conseguir emprego após a experiência do cárcere:

Às vezes a pessoa vai para uma entrevista e tem tudo pra dar certo. Quando é depois, não é chamada. Eu passei por umas entrevistas no comércio de Maceió. Fui pra uma loja, aí a moça disse: 'Aguarde...'. Depois da entrevista, levou os meus dados. Acho que puxaram lá a minha ficha. Até hoje, sempre é isso: 'Fique aguardando'. Aí, você tem $99 \%$ de chance, mas depois, desaparece. Eu acho que é por ser ex-presidiária. Eles não perguntam sobre isso na entrevista, mas pedem 'Nada Consta'. Aí...

Embora tenha tentado vencer a estigmatização no pós-cárcere, através dos esforços de estudar e trabalhar, ela deixou para trás, em nome de um novo amor, importantes oportunidades de conquistar espaços no mercado de trabalho, algo por ela tão almejado.

\subsection{Fátima}

Fátima é uma mulher jovem e bonita. Aos 29 anos, é morena, magra, tem longos cabelos negros e lisos, que chegam até a cintura. Ela aparenta bem menos idade e se veste com roupas de adolescente. A sua performance evidencia estereótipos de feminilidade: ela gesticula muito ao falar, mexendo sempre nos cabelos e cruzando as pernas.

A maternidade aparece como outro elemento identitário muito importante para Fátima. Ela tem dois filhos, sendo um de nove anos e outro de dois. Quando foi presa, tinha somente o primeiro, que ficou sob a responsabilidade de sua mãe. No período em que esteve no cárcere, sua mãe ia visitá-la duas vezes por semana e levava a criança, de modo que Fátima não perdeu o contato com o filho durante o encarceramento. Entretanto, isso não impediu que ela sofresse pela ausência do convívio cotidiano e pela falta de autonomia diante da forma como a mãe cuidava da criança. "Quando estive presa, meu filho mais velho sentia falta de mim. Ele 
O lado oculto das prisões femininas: representações dos sentimentos em torno do crime e da pena.

chegava lá e começava a me abraçar, me beijar. Aí dizia: 'Ah, Mainha, a Vó bateu em mim com a vassoura'. Uma coisa que eu não faço é bater. Eu sofria com isso".

Fátima fala do preconceito da família do atual companheiro, no início do relacionamento, pelo fato de ser ex-presidiária. Eles não aceitavam a relação deles. No entanto, faz questão de ressaltar que tal resistência foi vencida aos poucos, no convívio cotidiano, quando todos, de fato, passaram a conhecê-la. Afirma que hoje tem três famílias: a sua originária, a do segundo marido e a do atual companheiro. Essas famílias são um importante suporte emocional e financeiro para ela. Tudo isso demonstra os seus esforços em representar elementos identitários positivos, que proporcionem, tal como afirma Goffman, a reconstituição do self (GOFFMAN, 2003a).

Durante o tempo em que esteve presa, além da mãe e do filho, Fátima recebia a visita da irmã, dos irmãos, dos colegas, das comadres. A visita durante o encarceramento é apontada por ela como algo muito bom, que contribuía para manter a ligação com as pessoas. No entanto, não foi suficiente para evitar que muitos se afastassem dela.

Quando eu saí da prisão, as amizades ainda continuaram. Eles me veem, falam comigo assim: 'Oi, oi', mas não é a mesma coisa. Sempre muda, né? Eu tinha algumas amizades antigamente que eu não tenho mais de volta. Eu tinha amizade com polícia, com delegado. Tinha muita amizade boa também, e se afastaram.

Assim que saiu da prisão, conseguiu emprego em uma instituição de ensino superior, por força de convênio com o Superintendência de Administração penitenciária. Gostava do trabalho, mas critica as regras ali estabelecidas para os/as trabalhadores/as conveniados/as, que envolviam, entre outras orientações, a proibição de falar com alunos da instituição, algo que ela define como preconceituoso. Ela diz:

A gente não podia falar com nenhum dos estudantes. Se eles veem a gente falando com estudante, eles colocam a gente pra fora do emprego. Não pode! Eu já acho que isso é um preconceito. Eu disse: 'eu só num boto um processo nesse colégio porque eu não sou ninguém, entendeu?'. Porque eu acho que os direitos deveriam ser iguais. Um chefe lá do colégio me proibir de falar com você? Acho que isso não existe. Não pode dar nem um 'Oi', nem um 'Bom-dia'?

Essas palavras de Fátima são ilustrativas dos efeitos cruéis produzidos pelo cárcere, particularmente no aspecto de ser vítima do preconceito que, em última 
instância a faz contactar com a situação de não ser reconhecida enquanto sujeito e sofrer o drama de pertencer a uma sociedade que não lhe permite viver o sentimento de pertencimento. Sua reflexão demonstra a indignação diante da estigmatização vivenciada num espaço de trabalho que, em tese, é destinado, justamente, a pessoas libertas do cárcere, aparecendo como uma oportunidade de emprego. Ao afirmar que não é "ninguém", Fátima está reconhecendo as limitações de seu status de ex-presidiária, sem condições financeiras de levar adiante um enfrentamento judicial dessa natureza. Embora suas palavras expressem certa atitude contestadora, sua história de vida com o tráfico e com a prisão parece destituí-la da condição de alguém apto a lutar pela igualdade, o que também demonstra como as sombras da prisão atingem sua autonomia e, portanto, mortificam o self, deixando marcas estigmatizantes.

É difícil pra arrumar emprego, porque você é expresidiária. Mas a minha vontade é trabalhar com carteira fichada. Eu já procurei muito. Eu trabalho em qualquer coisa: casa de família, cozinha, auxiliar de cozinha, garçonete, que é a minha profissão. Só que é raro de dar emprego. Não peguei o 'Nada consta' ainda, que é depois de cinco anos. Não é fácil, não. É ruim mesmo. Só quem sabe é quem passa.

Diante dessa realidade, Fátima faz reflexões sobre o passado na prisão:

O que mudou na minha vida durante o tempo que tive presa foi que passei a dar valor às coisas, que antigamente eu não dava. Até minha vida. Minha vida mudou depois da prisão. Eu fiquei mais feia (risos), tô mais velha. Porque ninguém fica mais novo... Perdi muito tempo, minha juventude ali dentro. Eu tinha vinte e quatro anos quando fui presa. Tô com vinte e nove, vou fazer trinta. É uma vida perdida, num é, não? Dois anos? É uma vida.

Ao olhar para o futuro, Fátima não reflete sobre si mesma, mas sim sobre seus filhos, o que demonstra a importância da maternidade na sua vida. No entanto, é na sua experiência na prisão que parece estar o parâmetro para investir na educação dos filhos e formá-los como cidadãos: “O que eu espero pra o futuro é que meus filhos estudem e se formem, que não vão parar onde eu parei, no presídio. É o que eu digo a eles direto: 'Estudem, estudem'”. Esse olhar sobre os filhos representa bem a autocrítica com relação ao que foi vivenciado no passado, o desejo de mudar e o desejo de se tornar exemplo na formação dos filhos. É o self em reconstrução. 
O lado oculto das prisões femininas: representações dos sentimentos em torno do crime e da pena.

\subsection{Bernadete}

Bernadete tem 26 anos de idade. Alta, tem olhos verdes e cabelos lisos, pintados ora de loiro forte, ora de ruivo. Ela vem de uma família de classe média baixa e, segundo ela, os pais fizeram de tudo a fim de dar o melhor para ela e os cinco irmãos. A infância, para ela, "nem foi as mil maravilhas e também num foi tão ruim, não".

A adolescência de Bernadete foi marcada pela rebeldia, e foi esse comportamento, acentuado pelo uso de drogas, que a levou ao crime e à prisão, por duas vezes. A primeira condenação, aos 19 anos, por homicídio, acarretou uma pena de 23 anos, quatro meses e 15 dias. A segunda condenação, aos 25 anos, por tentativa de homicídio, ocorrida quando ela estava em livramento condicional referente à primeira condenação, resultou em uma pena de 13 anos. No total, são 36 anos, quatro meses e 15 dias de pena a cumprir.

A primeira condenação de Bernadete levou-a a passar dois anos na prisão, tempo que avalia como ruim, mas que não deixou de ser uma lição. Recebia a visita da mãe, de dois irmãos e da filha pequena, definindo esse momento como "a melhor coisa que acontecia". Afirma que somente aos poucos foi percebendo que "família é tudo", algo que ela não valorizava antes da prisão.

No caso de Bernadete, o processo de sofrimento no cárcere parece fazer um movimento contrário ao sentido de perdas e rupturas que convencionalmente marcam outras histórias de vida, já que proporcionou, segundo ela, a valorização de algo por ela antes desprezado: as relações familiares. Como sua narrativa sugere que tais relações anteriormente não eram constitutivas de uma identidade feminina típica nela inscrita, foi a segregação que a levou a reconhecer a importância desses lados. É como se sua autoidentidade fosse agora definida a partir de uma identidade feminina convencional que anteriormente não existia, o que envolve não apenas a relação com pais e irmãos, mas também a maternidade. Em outras palavras, essa valorização tardia da família, ocasionada apenas pela força da segregação prisional, sugere os efeitos do cárcere sobre os elementos identitários de Bernadete. Com a prisão, ela passa a considerar a importância dos laços afetivos em sua vida, o que sugere uma valorização das relações afetivas e do fortalecimento dos velhos vínculos.

Quando saiu pela primeira vez do presídio, aos 21 anos, Bernadete recebeu todo o apoio da família, que se esforçava para que ela não voltasse ao crime e ao cárcere. Ainda em liberdade, buscou auxílio em uma igreja evangélica, mas não gostou, porque as pessoas diziam que era só máscara. Ela diz: "Eu num acho que era só máscara, eu acho que eu me esforcei, porque pelo que eu me conheço, eu acho que eu não tinha capacidade pra isso, não. Eu tava tentando, só que ninguém me ajudou. Fiquei sozinha, me revoltei". Ela afirma que hoje não tem religião, mas 
que reza o Pai-Nosso, quando se lembra, embora não acredite muito, por causa das injustiças do mundo.

Este relato, que revela as impressões dos outros que a conheciam acerca do seu suposto novo comportamento, demonstra como Bernadete busca representar as tentativas de enquadrar-se em um padrão de conduta que seja aceito no meio social para o qual ela retornou em liberdade. Suas tentativas de representar novos elementos identitários dissociados daqueles que sempre marcaram sua vida de rebeldia e liberdade plena parecem não ter tido êxito, diante da estigmatização vivenciada nas relações sociais. A referência expressa à revolta sentida diante da impressão dos outros pode sugerir que o seu investimento em reconstruir sua autoidentidade a partir de novos parâmetros de valor aos quais ela não está intimamente relacionada tenha permanecido apenas no campo da representação de um self incompatível com o que ela parece se identificar.

Em outra situação, essa questão também fica bastante evidenciada: na prisão, Bernadete não trabalhou nem estudou. Chegou a fazer um curso de bijuteria, com certificado, mas, segundo ela, isso não a ajudou a encontrar emprego. Rasgou o certificado porque achava que acarretava discriminação, embora o documento não revelasse a condição de ex-presidiária. $O$ único emprego que conseguiu foi no frigorífico de uma pessoa da família, que não deu certo porque a acusaram de furtar um relógio, que na realidade havia sido furtado por outra pessoa. Ao descobrirem o verdadeiro autor do crime, não se desculparam com ela, o que a levou a ficar revoltada e quebrar parte do frigorífico. Tentou outros empregos e não conseguiu. Afirma que desistiu: “Tô fora, desisti. Dá pra mim, não. Já comecei nessa vida e acho que eu vou morrer assim. Todo mundo fica discriminando, ninguém dá uma oportunidade. Fica difícil, revolta". Nessa fala de Bernadete parece estar situada a sua indignação diante da estigmatização vivida, sobretudo diante do fato concreto de ter sido acusada de um crime que não cometeu - o furto -, já que sua condição de ex-presidiária a colocava em posição de alvo das acusações.

Bernadete afirma que a segunda vez na prisão está sendo mais difícil, porque sofre com a falta dos filhos, já que praticamente não teve oportunidade de cuidar deles. Como o primeiro período de permanência no cárcere, de acordo com seu relato, foi fundamental para a descoberta dos valores das relações familiares, lamenta porque os dois filhos menores já não a reconhecem como mãe e estranham quando vão visitá-la na prisão. Além disso, sofre porque a filha mais velha, de seis anos, sabe que ela está presa e chora com saudades. Ao expressar esses sentimentos com relação aos filhos, ao não vivido, às referências maternas perdidas, Bernadete demonstra como a maternidade, aos poucos, se instala em sua vida como uma nova referência identitária.

Sobre a prisão, Bernadete afirma: "é o fim da vida". Nessa expressão estão implícitas todas as impressões, sensações, frustrações e revoltas de uma mulher

Latitude, Vol. 7, nº 2, pp. 51-68, 2013 
O lado oculto das prisões femininas: representações dos sentimentos em torno do crime e da pena.

que tem a autonomia como sua principal marca identitária e que, tolhida pelo espaço penitenciário, busca novos elementos e novas relações - familiares e afetivas - para a reconstrução do self. Para o futuro, Bernadete espera sair da prisão, cuidar dos filhos e "levar uma vida de gente, de uma pessoa normal". Ela sabe que, com uma vida marcada por tantos altos e baixos, duas condenações penais e as marcas do cárcere, sua história guarda elementos que fogem ao padrão de normalidade de uma sociedade pautada por valores que para ela são indiferentes.

\section{Conclusão}

As reflexões apresentadas neste texto tiveram o propósito apresentar algumas linhas de reflexão que defendem a existência de uma especificidade da experiência carcerária quando o crime e a condenação envolvem a figura de uma mulher. Buscamos trazer à tona os sentimentos e as representações sociais que rondam o universo de mulheres que viveram a experiência do cárcere a partir de sua condenação à pena privativa de liberdade. No contexto brasileiro, marcado por um sistema penitenciário precário e pautado por políticas criminais assexuadas e alheias às questões de gênero, aparecem narrativas que apontam para uma realidade que escapa ao olhar da sociedade: o sofrimento efetivamente desencadeado pelas sombras do crime praticado e pela experiência do encarceramento.

A dupla punição vivenciada por mulheres condenadas ao cárcere somente é percebida em seus discursos, que revelam histórias de estigmatização, rupturas afetivas e perdas profissionais, resultantes da quebra das expectativas de gênero, tendentes a atribuir às mulheres status e papeis aparentemente incompatíveis com a prática de crime.

A ausência de políticas sociais voltadas para a recomposição dos laços afetivos e de incentivo ao trabalho/emprego situa as mulheres apenadas em uma condição de extrema fragilidade diante do devir. Assim, o sofrimento da prisão não se limita ao período encarceramento, mas se estende ao longo da vida dessas mulheres, deixando marcas indeléveis em suas histórias de vida.

As expectativas presentes no imaginário coletivo em torno do comportamento feminino, vinculado hegemonicamente às práticas maternais, amplifica o sofrimento das mulheres que cometeram crimes, na medida em que seu ato delituoso, por si só, representa uma ruptura com o que se espera do comportamento feminino nas relações sociais ou interpessoais. Nossas reflexões reforçam, portanto, a ideia de que as mulheres que cometem crimes sofrem uma dupla condenação: a determinada pelas "normas jurídicas penais" e a determinada pelas "normas de gênero". Negar essa especificidade significa assumir uma 
posição de neutralidade frente às diferenças sociais existentes entre mulheres e homens que, efetivamente, são uma realidade no mundo contemporâneo.

\section{Referências}

ALIMENA, Carla Marrone. A tentativa do (im)possível: feminismos e criminologias. Rio de Janeiro: Editora Lumen Juris, 2010.

ALMEIDA, Rosemery de Oliveira. Mulheres que matam: universo imaginário do crime no feminino. Rio de janeiro: Relume Dumará: UFRJ, Núcleo de Antropologia da Política, 2001.

ALVES, Amy Avelina Coutinho de Faria. De gente a gente só tem o nome: a mulher no sistema penitenciário de Sergipe. São Cristóvão: UFS; Aracaju: Fundação Oviêdo Teixeira, 2001.

BLANCHETTE, Kelley; BROWN, Shelley Lynn. The assessment and treatment of women offernders. England: Wiley, 2006.

BOCK, Gisela. Questionando dicotomias: perspectivas sobre a história das mulheres. In Variações sobre sexo e gênero (Orgs. Ana Isabel Crespo, Ana Monteiro-Ferreira, Anabela Galhardo Couto, Isabel Cruz e Tereza Joaquim). Tradução de AnaMonteiro-Ferreira. Lisboa: Livros Horizonte, 2008.

CARDIA, Nancy. Direitos humanos e exclusão moral. In Sociedade e Estado. Volume X, n 2, Jul-Dez, 1995.

CARLEN, Pat. Women's imprisonment: cross-national lessons . In Women and punishment, Pat Carlen, Devon: William Publishing, 2003.

COSTA, Elaine Cristina Pimentel. Amor bandido: as teias afetivas que envolvem a mulher no tráfico de drogas. Maceió: Edufal, 2008.

CUNHA, Manuela Ivone P. da. A reclusão segundo o gênero: os estudos prisionais, a reclusão de mulheres e a variação dos contextos da identidade. In AAVV, Educar o Outro: As Questões de Género, dos Direitos Humanos e da Educação nas Prisões Portuguesas, Coimbra, Publicações Humanas: 2007, p. 80-89. DUARTE, Vera. A presença feminina na delinquência juvenil: olhares e silêncios. In Género e ciências sociais, Sofia Neves (coord.). Maia: Edições ISMAI, 2011.

ESPINOSA, Olga. A mulher encarcerada em face do poder punitivo. São Paulo: IBCCRIM, 2004.

FOUCAULT, Michel. Vigiar e punir: história da violência nas prisões. 25 ed.. Petrópolis: Vozes, 1987.

FRASER, Nancy. Políticas feministas na era do reconhecimento: uma abordagem bidimensional da justiça de gênero. Tradução de Heloísa Eugênia Villela Xavier. In Cristina Bruschini e Sandra G. Unbehaum (orgs.) In Gênero, democracia e sociedade brasileira. São Paulo: FCC: Ed. 34, 2002, p. 61-78. 
O lado oculto das prisões femininas: representações dos sentimentos em torno do crime e da pena.

GELSTHORPE, Loraine. Feminism and criminology. In The Oxford handbook of criminology, 3 ed. Organizado por Mike Maguire, Rod Morgan e Robert Reiner, Oxford: University Press, 2002.

GOFFMAN, Erving. A representação do eu na vida cotidiana. 11 ed.. Petrópolis: Vozes, 2003a.

Estigma: notas sobre a manipulação da identidade deteriorada. 4 ed.. Rio de Janeiro: LTC, 2004.

HEIDENSOHN, Frances. Gender and crime. In The Oxford handbook of criminology, 3 ed. Organizado por Mike Maguire, Rod Morgan e Robert Reiner, Oxford: University Press, 2002.

KLEIN, Dorie. The etiology of female crime: a review of the literature. In The criminal justice system and women, Barbara Raffel Price e Natalie J. Sokoloff. Nova York: Clark Boardman Company, Ltd., 1982.

LEMGRUBER. Julita. Cemitério dos vivos: análise sociológica de uma prisão de mulheres, 2 ed, revista e atualizada. Rio de Janeiro: Forense, 1999.

MATTOS, Virgílio de. A visibilidade do invisível: entre o "Parada, polícia" e o alvará de soltura - Criminalização da pobreza e encarceramento feminino em Belo Horizonte no início do século XXI - Percurso e conclusões de um grupo de pesquisas sobre criminalidade, violência e direitos humanos em duas unidades prisionais femininas de Belo Horizonte. Belo Horizonte: Fundação MDC, 2008. MELLO, Marcelo Pereira de. A casa de Detenção da Corte e o perfil das mulheres presas no Brasil durante o século XIX. In Gênero: Núcleo transdisciplinar de Estudos de Gênero - NUTEG - v. 2, n.1 (2 sem. 2000).Niteróis: EdUFF, 2000. PERROT, Michele. As mulheres ou os silêncios da história. Tradução de Viviane Ribeiro. Bauru: EDUSC, 2005.

Minha história das mulheres. Tradução de Ângela M. S. Corrêa. São Paulo: Contexto, 2007.

Os excluídos da história: operários, mulheres e prisioneiros. São Paulo: Paz e Terra, 2010. PERRUCI, Maud Fragoso de Albuquerque. Mulheres encarceradas. São Paulo: Global, 1983.

SOARES, Bárbara Musumeci. ILGENFRITZ, Iara. Prisioneiras: vida e violência atrás das grades. Rio de Janeiro: Garamond, 2002.

WILKINSON, Christine. Women's release from prison: the case for change. In Women who offend, Gill McIvore (org.). London and Philadelphia: Jessica Kingsley Publishers, 2006.

WORRALL, Anne. Rendering women punishable: the making of a penal crisis. In Women and punishment, Pat Carlen, Devon: William Publishing, 2003. 